\title{
Clean Coal Utilization Based on Underground Coal Gasification Integrated Solid Oxide Fuel Cells and Carbon dioxide Sequestration
}

\author{
Prabu V*, Jayanti S \\ Indian Institute of Technology Madras, Chennai, India \\ * Corresponding author. Tel: +4422575152 E-mail: vprabu1979@yahoo.co.in
}

\begin{abstract}
Underground coal gasification (UCG) is a cl ean coal technology which converts coal into a combustible gas in situ without mining and without bringing up the ash contained in the coal. Thus, the attendant problems of coal washing, ash handling and disposal can be avoided. The combustible gas mixture, consisting primarily of hydrogen, methane, carbon monoxide--all of which are fuels for an solid oxide fuel cell (SOFC) system-- and carbon dioxide, can be fed to a battery of SOFC after gas cleaning to remove hydrogen sulphide and other impurities. A large portion, typically $50 \%$, of the chemical energy contained in the product gas can be converted into electrical energy by the SOFC. The exhaust gases from the SOFC are typically at a temperature of the order of 600 to $800 \mathrm{deg} \mathrm{C}$. Heat energy from these will be extracted to produce steam, part of which will be used for UCG and the rest will be sent for SOFC internal reforming and shifting reactions. The exhaust gases, consisting primarily of carbon dioxide and steam, will be finally fed through a condenser and will then be sent for compression and sequestration. Thus, the overall system envisaged makes use of oxygen-fed UCG and SOFC to generate electrical energy and an exhaust gas consisting primarily of carbon dioxide and the easily condensable steam which enables $\mathrm{CO}_{2}$ sequestration. The overall integrated system can be divided into five units namely underground coal gasification, UCG product gas purification, electrical power generation from SOFC, heat recovery system and carbon sequestration unit. An energy analysis with heat integration of all the systems for a nominal $500 \mathrm{MWt}$ will be discussed.
\end{abstract}

Keywords: Underground coal gasification, Solid oxide fuel cell, Carbon sequestration, Heat integration.

\section{Nomenclature}

$W_{\text {ele }}$ electrical work ..$k J$

F Faraday's constant ...................................

$K$ equilibrium reaction constant.......................

p partial pressure.......................................bar

$T$ mean temperature .....................................

$R \quad$ universal gas constant ................. $\mathrm{kJ} / \mathrm{kmol} \mathrm{K}$

$H \quad$ enthalpy .................................................

$\mathrm{N}_{\mathrm{H}_{2}}$ moles of hydrogen converted...............mol

$\Delta H_{R}$ Heat of reaction....................... kJ/mol

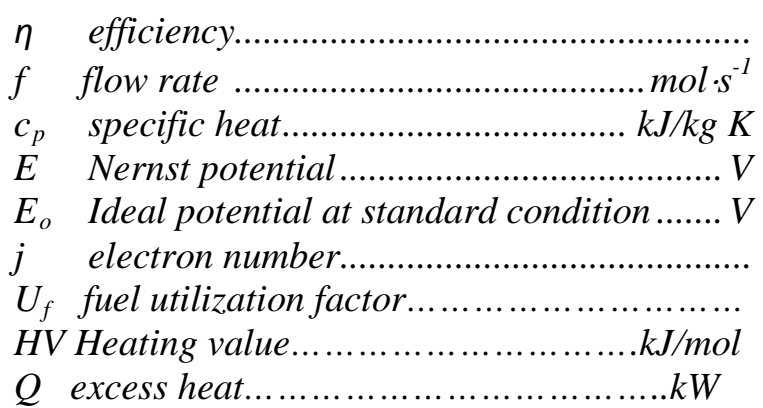

\section{Introduction}

Coal is the major fossil fuel in the world and $70 \%$ of electricity produced in India comes from coal. Coal is expected to be the mainstay of electricity generation in India for the next several decades. However, coal utilization is fraught with environmental problems. G iven that Indian coal typically has large ash content, its mining, washing, and final utilization in pulverized coal boilers leads to significant land, water and air pollution. The ash collected from the stacks also poses a disposal problem. On top of these, there is increased awareness of the need to reduce $\mathrm{CO}_{2}$ emissions into the atmosphere. Hence it is necessary to develop suitable technologies for coal conversion efficiently without environmental pollution.

Underground coal gasification (UCG) is a clean coal technology with in situ gasification having no mining problem, no a sh disposal, offering economical exploitation of low grade coal. It is a cl ean coal technology which enables exploitation of coal reserves in an 
environmental friendly manner. A large amount of work has been reported in the 1970 s and 80s on UCG [1-5] and there has been renewed interest in UCG as showed by a number of publications in the last decade [6-10]. These studies have focused on coal gasification per se and not much on $\mathrm{CO}_{2}$ sequestration. In the present paper, we describe a process by which UCG can be coupled to a solid oxide fuel cell (SOFC) system to develop an integrated power plant which makes use of the fuel gas from the UCG, generates electricity from it and leaves an exhaust gas consisting of $85 \% \mathrm{CO}_{2}$ which can therefore be readily sequestered. The layout of the proposed plant is described in Section 2 and a thermodynamic analysis of the system is discussed in Section 3.

\section{Description of the coupled UCG-SOFC system}

A schematic diagram of the integrated UCG-SOFC system is shown in Figure 1. The product gas from the UCG system typically has some particulate matter and impurities in the form of tar, sulphur and its compounds. These are removed as the gas passes through a c yclone separator, a gas filter unit and a tar removal unit. The hot gas from the cyclone separator exchanges heat with the clean gas coming from the tar removal system in a gas-to-gas heat exchanger. The clean fuel gas is further heated (by the hot anode side exhaust of the solid oxide fuel cell (SOFC) unit) and is mixed with steam and is fed to the anode side of the SOFC unit. The unused portion of hydrogen and carbon mono oxide ( $85 \%$ fuel utilization efficiency is assumed in the SOFC) is then fed to a combustor to completely convert the remaining fuel into $\mathrm{CO}_{2}$ and steam. These gases are fed to a condenser in which most of the steam is removed and the remaining gas, consisting mostly of $\mathrm{CO}_{2}$ is sent to the $\mathrm{CO}_{2}$ sequestration unit. The thermal energy in the exhaust gas of the combustor is used to generate steam in the condenser unit which is used for fuel reforming in the SOFC as well as for coal gasification in the UCG gasifier. Further, the thermal energy of the hot air from the cathode code is also used to preheat the air that is supplied to the cathode so as to maintain the SOFC temperature at the design condition. In order to eliminate nitrogen from the system (so as to facilitate $\mathrm{CO}_{2}$ sequestration), an air separation unit is used to supply oxygen in required quantity to the combustor (this is especially needed to maintain stable combustion as the anode gas from the SOFC contains only a small percentage of fuel, namely, $\mathrm{H}_{2}$ and $\mathrm{CO}$, the rest being $\mathrm{CO}_{2}$ and steam) as well as that required for gasification in the UCG gasifier unit. The flow paths of the various streams are shown in Figure 1.

The above coupling of the UCG with an SOFC enables proper thermal integration of the various units to produce electrical energy directly from the product gas of the UCG. Moreover, the combination of UCG and SOFC is such that the integration can be done in such a way that all the $\mathrm{CO}_{2}$ that is produced in the fuel utilization can be captured in a relatively straightforward manner without the need for an external $\mathrm{CO}_{2}$ absorption unit as is required in normal combustion of the UCG gas. One disadvantage however is the need to clean the UCG gas to remove tar and sulphur products so that it can be used in an SOFC. The technology for the required gas cleaning already exists; the calculations described in the next section show that the gas cleaning can also be done without a significant energy penalty resulting in a combined system with a significantly higher overall thermal efficiency and little environmental pollution.

\section{Thermodynamic model and analysis}

The overall integrated plant consist of five units, namely, underground coal gasification, UCG product gas purification, electrical power generation from SOFC, heat recovery systems and carbon sequestration unit. An energy balance on these units has been carried out to determine 
the overall utilization of energy. The UCG system is considered to be operating at atmospheric pressure and the bituminous grade coal in underground undergoes partial oxidation and gasification in presence of pure oxygen to produce calorific value synthesis gas. The electrical efficiency of SOFC fuel cell is found out based on the shifting, reforming and electrochemical reaction with reaction kinetics.

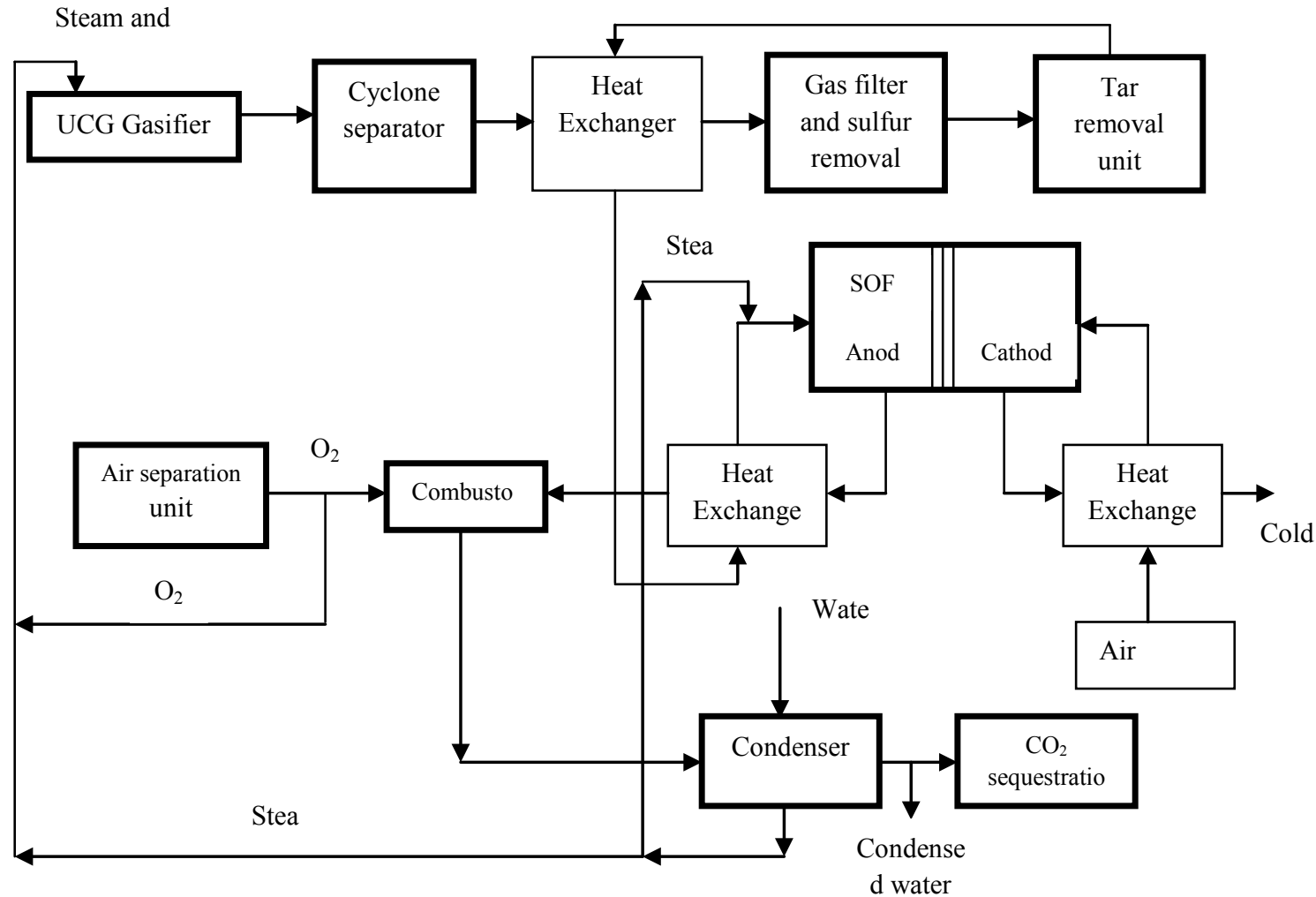

Fig.1. Schematic of the integrated underground coal gasification with solid oxide fuel cell

\subsection{UCG Plant}

A $500 \mathrm{MW}$ of product gas generated from UCG and the flow rate of input and output stream of gases and its molar composition has taken from Lawrence Livermore national laboratory (LLNL) literature [11] and used for the basis of theoretical calculation. Table 1 represents the product gas molar composition and total product gas flow rate from UCG of $2600 \mathrm{~mol} / \mathrm{s}$.

Table 1. Product gas composition from UCG plant

\begin{tabular}{ccc}
\hline Species & Mole fraction & Product gas flow rate[mol/s] \\
\hline $\mathrm{N}_{2}$ & 0.018 & 47.36 \\
$\mathrm{CO}$ & 0.11 & 289.47 \\
$\mathrm{CO}_{2}$ & 0.44 & 1157.89 \\
$\mathrm{H}_{2}$ & 0.37 & 973.68 \\
$\mathrm{CH}_{4}$ & 0.05 & 131.58 \\
\hline
\end{tabular}

Heat of combustion of product gas $(\mathrm{HV})=190 \mathrm{~kJ} / \mathrm{mol}$

Product gas flow rate from UCG to SOFC $\left(\mathrm{f}_{\mathrm{p}}\right)=2631.58 \mathrm{~mol} / \mathrm{s}$

Total injection flow rate of steam and oxygen $=2255.63 \mathrm{~mol} / \mathrm{s}$

Injection mole fraction of oxygen $=0.47$

The UCG gasifier operating temperature is assumed to about $800^{\circ} \mathrm{C}$ in oxyfuel mode. Pure oxygen from air separation unit and steam generated from condenser unit are injected into 
injection hole and the gasified products at $650^{\circ} \mathrm{C}$ are collected from the production hole of UCG.

\subsection{UCG product gas purification system}

In UCG system, volatile matter liberated during combustion, gasification and pyrolysis zone will move along the cavity and make contact with the fresh coal. This would results in product gas enriched with tar content since there is no further thermal cracking [12]. The issue of removal of mercury, arsenic and other trace metals is not addressed here as not much is known about their formation and presence in the UCG gas. In order to utilize these product gases in SOFC for power generation, it is necessary to remove the tar and sulfur content impurities. Cyclone separator and ceramic filters are used to remove the particulate matter and alkali compounds from product gases before the tar removal. A wet electrostatic precipitator is used for tar condensation and removal. The purified gas stream is cooled to about $50^{\circ} \mathrm{C}$ and the enthalpy is again gained from the inlet gas stream of purification system and fed into the SOFC.

\subsection{SOFC fuel cell system}

The purified hot gas stream from with steam is introduced at the anode side of the SOFC. To avoid the carbon deposition in SOFC, a steam to carbon ratio of 2:1 is assumed [13]. Excess oxygen of $400 \%$ in air is supplied at the cathode side to recover the generated heat energy. The operating temperature of SOFC is assumed to be $700^{\circ} \mathrm{C}$. The temperature of exit stream from anode and cathode side is same as the operating temperature of SOFC. In IRSOFC (Internal reforming SOFC), only hydrogen is assumed to undergo oxidation for electric power generation. Carbon monoxide, methane undergoes reforming and water gas shifting reactions [Eq. (1)] with steam and produces hydrogen. High operating temperature of SOFC is suitable for reforming and shifting reaction which converts the $\mathrm{CO}$ and other hydrocarbons to hydrogen. A fuel utilization factor of 0.85 is assumed for the fuel cell.

Reforming reaction: $\quad \mathrm{CH}_{4}+\mathrm{H}_{2} \mathrm{O} \stackrel{\mathrm{K}_{\text {ref }}}{\longleftrightarrow} \mathrm{CO}+3 \mathrm{H}_{2}$
Water gas shifting reaction: $\mathrm{CO}+\mathrm{H}_{2} \mathrm{O} \stackrel{\mathrm{K}_{\text {shf }}}{\longleftrightarrow} \mathrm{CO}_{2}+\mathrm{H}_{2}$

$$
\begin{aligned}
& \mathrm{K}_{\text {ref }}=[\mathrm{CO}]\left[\mathrm{H}_{2}\right]^{3} /\left[\mathrm{CH}_{4}\right]\left[\mathrm{H}_{2} \mathrm{O}\right] \\
& \mathrm{K}_{\text {shf }}=\left[\mathrm{H}_{2}\right]\left[\mathrm{CO}_{2}\right] /[\mathrm{CO}]\left[\mathrm{H}_{2} \mathrm{O}\right]
\end{aligned}
$$

where $\mathrm{K}_{\text {ref }}$ and $\mathrm{K}_{\text {shf }}$ are the equilibrium constants for reforming and shifting reaction respectively. The equilibrium constants are calculated using the temperature dependent polynomial expressions [14]. The equilibrium gas composition can be determined using Eq. (2\&3).

\subsection{Estimation of Overall Thermal Energy Conversion Efficiency}

The overall thermal energy conversion efficiency $(\eta)$ of the coupled UCG-SOFC process can be estimated from the thermal energy content in the UCG gas and the electrical power output from the SOFC system. The latter is estimated as follows. The cell e.m.f, E, of the SOFC is calculated for the particular concentrations of hydrogen, oxygen and steam produced $\left(\mathrm{p}_{\mathrm{H}_{2}}, \mathrm{p}_{\mathrm{O} 2 \text {, }}\right.$ $\mathrm{p}_{\mathrm{H}_{2} \mathrm{O}}$ ) used in the cell using the Nernst equation [15]:

$$
\mathrm{E}=\mathrm{EO}+(\mathrm{RT} / \mathrm{jF}) \ln \left[\left(\mathrm{p}_{\mathrm{H}_{2}} \cdot \mathrm{p}_{\mathrm{o}_{2}}{ }^{1 / 2}\right) / \mathrm{p}_{\mathrm{H}_{2} \mathrm{O}}\right]
$$


where Eo is the ideal potential at standard condition, $\mathrm{j}$ is the electron number.

The electrical power output from the SOFC is then calculated as

$$
\mathrm{W}_{\text {ele }}=\mathrm{EN}_{\mathrm{H}_{2}} \mathrm{jF}
$$

where $\mathrm{N}_{\mathrm{H}_{2}}$ is the number of moles of hydrogen, and $\mathrm{F}$ is the Faraday's constant.

The overall thermal energy conversion efficiency can now be calculated by dividing the electrical power output by the thermal energy flow rate in the UCG gas:

$$
\eta=\mathrm{Wele}_{\mathrm{el}} /\left(\mathrm{f}_{\mathrm{p}} \times \mathrm{HV}\right)
$$

where $f_{p}$ is product gas flow rate from UCG in $\mathrm{mol} / \mathrm{s}$ and $\mathrm{HV}$ is the heating value of the product gas from UCG.

\subsection{Estimation of the air inlet temperature for the SOFC}

Energy balance can be made over the SOFC fuel cell system to calculate the air inlet temperature to the cathode side [Fig.2]. Eq. (7) gives the excess energy generated in the fuel cell is taken up by the incoming air and gas stream to maintain a constant operating temperature in the cell.

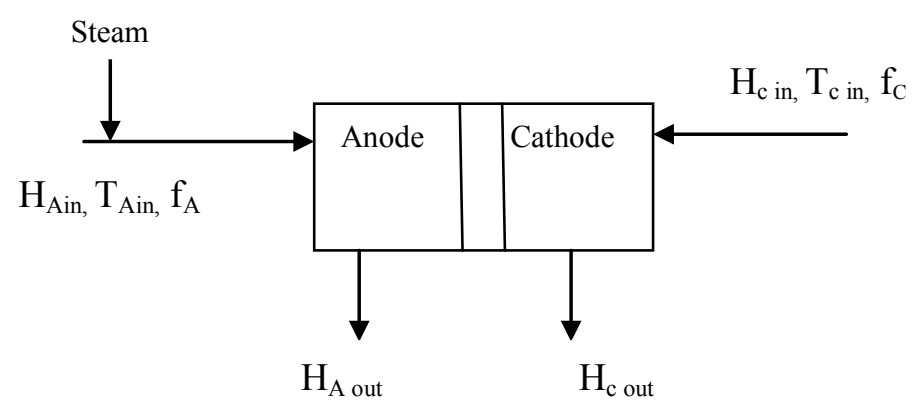

Fig.2. Schematic diagram of SOFC Model

$$
\Delta \mathrm{H}_{\mathrm{R}}=\mathrm{W}_{\mathrm{ele}}+\mathrm{Q}
$$

where $\Delta \mathrm{H}_{\mathrm{R}}$ is the heat of reaction $(\mathrm{kJ} / \mathrm{mol}), \mathrm{Q}$ is the excess energy generated in the fuel cell.

$$
\mathrm{Q}=\mathrm{f}_{\mathrm{A}} \int_{\mathrm{T}}^{\mathrm{T}_{\text {Sofc }}} \mathrm{Cp} \mathrm{dT}+\mathrm{f}_{\mathrm{C}}\left(\mathrm{H}_{\mathrm{SOFC}}-\mathrm{H}_{\mathrm{C} \text { in }}\right)
$$

where $f_{A}$ and $f_{c}$ are the input flow rates of anode side gas stream and cathode side air stream respectively.

From Eq. (8), the air inlet temperature to cathode side of the fuel cell is calculated.

\subsection{Heat recovery system}

The outlet gas from anode and cathode of SOFC at high temperature of $700^{\circ} \mathrm{C}$ are utilized for the heat recovery system. The inlet gas streams of cathode and anode are heated using heat exchangers by their respective outlet gas streams. The trace quantity of unconverted gas from SOFC can be burnt in a combustor with oxygen and the hot gas from combustor has sent to the condenser. A fresh steam is generated from condenser which is then supplied to the SOFC 
cathode inlet and UCG injection hole. The two heat exchangers at the inlet of SOFC system of cathode and anode and the combustor and the condenser for fresh steam generation will constitutes the heat recovery system of the integrated system.

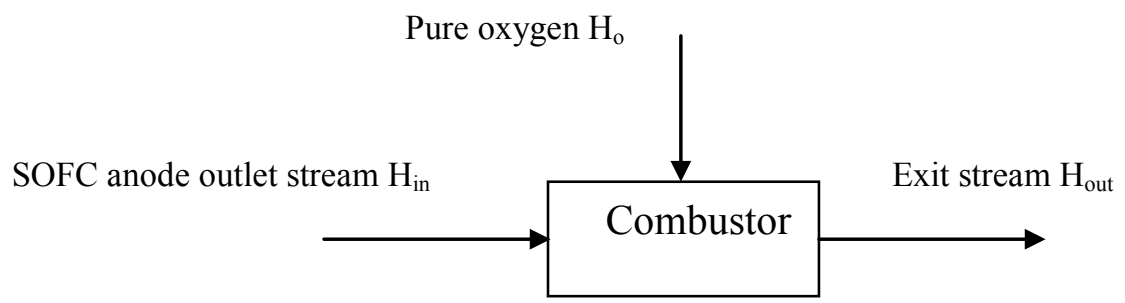

Fig.3. Schematic diagram of combustor model.

Complete combustion of remaining hydrogen, carbon monoxide and trace amount of methane are assumed in the combustor. Pure oxygen of $150 \%$ in excess of stoichiometric requirement for complete combustion is supplied to the combustor. The temperature of the exit stream from combustor (Fig.3) can be calculated from the enthalpy balance [Eq. (9)] over combustor.

$$
\mathrm{H}_{\text {in }}+\mathrm{H}_{\mathrm{o}}=\mathrm{H}_{\text {out }}
$$

Hot stream inlet $\mathrm{T}_{1}, \mathrm{H}_{1}, \mathrm{f}_{\mathrm{H}}$

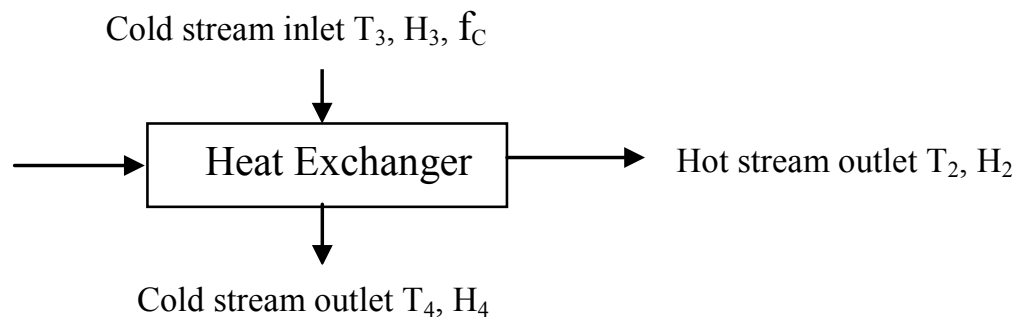

Fig.4. Schematic diagram of Heat Exchanger model

Fig.4 represents the schematic diagram of heat exchanger model. The cold stream outlet temperature can be calculated from the enthalpy balance equation [Eq. (10)].

$$
\mathrm{f}_{\mathrm{H}}\left(\mathrm{H}_{1}-\mathrm{H}_{2}\right)=\mathrm{fc}_{\mathrm{T}_{3}}^{\mathrm{T}_{4}} \mathrm{Cp} \mathrm{dT}
$$

where $f_{H}$ and $f_{C}$ are the flow rates of hot and cold streams respectively.

\section{Results and Discussion}

An overall energy balance is made for the entire thermodynamic model for the integrated system of UCG and SOFC. The steam generated from condenser at $600^{\circ} \mathrm{C}$ is sent to the UCG and SOFC with approximately equal proportion.

The hot product gas from the UCG plant enters the purification system at $650^{\circ} \mathrm{C}$ and cooled in a heat exchanger to $200^{\circ} \mathrm{C}$ and then it enters into the filter. Small particulate matters and condensed alkali compounds are filtered through the gas filter. Particulate free gases are then entered into the wet electrostatic precipitator to remove the tar which is enriched in the product gases. The tar free product gas are coming out from the wet ESP at about $50^{\circ} \mathrm{C}$ are heated to about $525^{\circ} \mathrm{C}$ using the exit gas stream of UCG. In order to raise the temperature of 
the product gas at about $650^{\circ} \mathrm{C}$ to meet the SOFC operating temperature, the purified gas is heated again with the outlet gas stream of SOFC at anode side.

Table 2. SOFC inlet and outlet gas stream composition.

\begin{tabular}{ccc}
\hline Species & Inlet stream mole percent & Outlet stream mole percent \\
\hline $\mathrm{N}_{2}$ & 1.28 & 1.19 \\
$\mathrm{CO}_{2}$ & 31.25 & 38.15 \\
$\mathrm{CO}$ & 7.81 & 1.64 \\
$\mathrm{CH}_{4}$ & 3.55 & 0.000044 \\
$\mathrm{H}_{2}$ & 26.28 & 6.52 \\
$\mathrm{H}_{2} \mathrm{O}$ & 29.83 & 52.5 \\
\hline
\end{tabular}

Table 2 represents the SOFC inlet and outlet gas composition of cathode side. In outlet gas stream, only a trace amount of methane is present and constitutes $50 \mathrm{~mole} \%$ of steam. The electrochemical work done by the SOFC can be calculated using the Nernst equation as $312.53 \mathrm{MW}$. Electrical efficiency of the SOFC cell is found as $62.5 \%$.

The unconsumed fuel from SOFC is burnt in the combustor with pure oxygen to extract more energy and the outlet gas is purely a composition of steam and carbon dioxide. The combustion of unconsumed fuel from SOFC in the combustor can be carried out using excess oxygen.

Table 3. Combustor inlet and outlet gas stream composition

\begin{tabular}{ccc}
\hline Species & Inlet stream mole percent & Outlet stream mole percent \\
\hline $\mathrm{N}_{2}$ & 1.08 & 1.125 \\
$\mathrm{CO}_{2}$ & 34.62 & 37.49 \\
$\mathrm{CO}$ & 1.49 & 0 \\
$\mathrm{CH}_{4}$ & 0.00004 & 0 \\
$\mathrm{H}_{2}$ & 5.91 & 0 \\
$\mathrm{H}_{2} \mathrm{O}$ & 47.64 & 55.62 \\
$\mathrm{O}_{2}$ & 9.25 & 5.77 \\
\hline
\end{tabular}

Table 3 shows the combustor outlet gas composition. Combustor outlet stream contains $37 \%$ of $\mathrm{CO}_{2}$ and $55 \%$ of steam which is then sent to the condenser to extract the heat energy. All the steam can be condensed and the pure $\mathrm{CO}_{2}$ is separated and sent to sequestration unit.

\section{Conclusion}

A fully integrated UCG-SOFC system is proposed to provide clean electrical energy from underground coal. The combination of UCG and SOFC is such that thermal as well as system integration of the two units can be carried out readily. A first-cut energy analysis, without including the cost of the air separation unit and the cost of compression of the $\mathrm{CO}_{2}$ for the purposes of, say, underground sequestration, gives an overall thermal efficiency of above $60 \%$. The combined system also utilizes fossil fuel in a clean manner without any particulate or gaseous emissions, thus providing a clean source of energy from conventional sources. 


\section{References}

[1] W.R.Aiman, W.T.Fisher, Lawrence Livermore National Laboratory Insitu coal gasification Program Quarterly Progress Report. January through March 1978, UCRL 50026-78-1

[2] C.B.Thorsness, J R Creighton. Review of underground coal gasification field experiments at HOE creek. Report No.UCRL-87662-Rev.1. U.S.DOE. Livermore, CA: Lawrence Livermore National Laboratory; 1983

[3] P.N.Thompson, Gasifying coal underground. Endeavour 1978;2: 93 -97

[4] A.M.Winslow, Numerical Model of coal gasification in a packed bed. Symbosium on combustion (international) 1977:16:503 - 513.

[5] C B Thorsness, E A Grens, A Sherwood, A one dimensional Model for Insitu coal gasification. Report No.UCRL-52523, U.S.DOE.Livermore, CA: Lawrence Livermore National Laboratory; 1978.

[6] M.S.Blinderman, D.N.Saulov, A.Y.Klimenko. Forward and reverse combustion linking in underground coal Gasification. Energy 2008; 33: 446-454.

[7] L Yang, J Liang, L Yu, Clean coal technology - Study on the pilot project experiment of underground coal gasification. Energy 2003;28:1445 - 1460

[8] L Yang, X Zhang, S Liu, W. Zhang, Field test of large-scale hydrogen manufacturing from underground coal gasification. International journal of Hydrogen Energy 2008; $33: 1275-1285$.

[9] G.Perkins, V.Sahajwalla. A Mathematical Model for the chemical reaction of a s emiinfinite block of coal in underground coal Gasification. Energy and fuels 2005;19:1679 1692

[10] S.Daggupati, N.Ramesh. R.N.Manadapati, S.M.Mahajani, A.Ganesh, D.K Mathur, R.K Sharma, P.Aghalayam, Laboratory studies on combustion cavity growth in lignite coal blocks in the context of underground coal Gasification. Energy 2010;35: 2374-2386.

[11] W.R.Aiman, M L Donohue, LLL insitu coal gasification project, Quarterly progress Report, Lawrence Livermore laboratory, Report No. UCRL 50026 -79 -3, 1979.

[12] T.Kivisaari, P Bjornbom, C Sylwan, B Jacquinot, D Jansen, A Groot, The feasibility of a coal gasifier combined with a high temperature fuel cell, Chemical Engineering Journal 100, 2004, pp $167-180$.

[13]A.O.Omosun, A.Bauen, N.P.Brandon, C.S.Adijman, D.Hart, Modelling system efficiencies and costs of two biomass-fuelled SOFC systems, Journal of power sources 131, 2004, pp $96-106$.

[14] S.Ghosh, S.De, Thermodynamic performance study of an integrated fuel cell combined Cycle- an energy analysis, Journal of Power and Energy 217, 2002, pp 137 -147.

[15] S.Ghosh, S.De, Energy analysis of a cogeneration using coal gasification and solid oxide fuel cell, Energy 31, 2006, pp 345 - 363. 